\title{
Potential Marine Benthic Habitat Map of Elkhorn Slough, California
}

\author{
Authors: Walton ${ }^{\mathrm{a}}$, K.; García-García ${ }^{\mathrm{b}}$, A.; Endris ${ }^{\mathrm{c}}$, C. \\ ${ }^{a}$ Department of Earth and Planetary Sciences, University of California Santa Cruz, 1156 High Street, Santa Cruz, \\ CA 95064, USA. Corresponding Author at: klwalton3@gmail.com, 1451 Chaparral Way, Livermore, CA 94551, \\ USA (permanent address). \\ ${ }^{\mathrm{b}}$ Department of Earth and Planetary Sciences, University of California Santa Cruz, 1156 High Street, Santa Cruz, \\ CA 95064, USA \& Department of Earth Sciences, Monterey Peninsula College, Monterey, CA 93940, USA \\ ${ }^{\mathrm{c}}$ Elkhorn Slough National Estuarine Research Reserve, 1700 Elkhorn Road, Watsonville, CA 95076, USA
}

\begin{abstract}
While marine benthic habitat maps have been created for approximately 34 percent of California's coastline, Elkhorn Slough currently does not have one. We have mapped for the first time Elkhorn's seafloor environments using a well-known classification system, which describes large-scale and small-scale features, bottom induration, vegetation, surface texture, and slope. This map was created in GIS using bathymetry data as well as data from sediment cores we collected. Sandy sediments were found in the Lower Slough, which is a high-energy environment, while mud or silt sediments dominated the rest of the Slough. Five classification categories were used to describe the Slough's seafloor: flat sandy sediments, sloped sandy sediments, flat muddy sediments, sloped muddy sediments, and eelgrass on flat sandy sediment. We used bathymetry data to interpret the Slough's sediment erosion and accretion over a period of 6 years. This preliminary map can be used to understand the location of various marine habitats, which is important for wildlife conservation and planning efforts in the Slough. Furthermore, this method of habitat mapping can be applied to other estuarine environments around the globe. The present work was initiated in 2015.
\end{abstract}

Keywords: habitat mapping, estuary, slough, geographical information systems, Elkhorn Slough 


\section{Introduction}

\subsection{Justification for Work}

The aim of Elkhorn Slough National Estuarine Research Reserve (ESNERR) is to maintain the health of the estuarine ecosystem of Elkhorn Slough and its surrounding watershed through research, preservation, and restoration (ESNERR, 2006). ESNERR has created several geographical information systems (GIS) projects to map and assess the land, such as the region's vegetation and wetlands. The present work provides a benthic habitat map of Elkhorn Slough, which has not previously been mapped, to aid ESNERR's monitoring of the subtidal environments. Using bathymetry and sediment cores, we constructed a GIS of the potential benthic habitats of the Slough following the classification code of Greene et al. $(1999,2007)$. Preliminary results were presented at the 2015 AGU Fall Meeting (Walton et al., 2015). This article presents current and completed work on the benthic habitat map.

\subsection{Study Area}

Elkhorn Slough is a shallow tidal embayment that extends about 11 kilometers inland from its mouth on the eastern-most point of Monterey Bay on the central coast of California (Figure 1). Flanked by intertidal mudbanks, tidal flats, and salt marshes, the main channel thalweg reaches a maximum depth of over 9 meters near the mouth, shoaling to depths less than a meter at the head. Elkhorn Slough contains a rich variety of intertidal and subtidal ecosystems that are extremely sensitive to the interactions between hydrodynamics and physical processes. The geologic history of Elkhorn Slough has been recently studied using sediment cores and seismic data (García-García et al., 2013). Results show that tectonic activity related to the movement of the San Andreas Fault blocked off the large drainage system about 500,000 years ago. This left Elkhorn Slough as a seasonal estuary with a small drainage flux (Schwartz, 2002). The sediment deposits after this change are mostly fine muds and salt marshes (García-García et al., 2013).

The recent history of the Slough shows a shift in the main channel geometry due to the construction of the Moss Landing Harbor and its jetties in 1947. The tides entering Elkhorn 
Slough transitioned from low- to high-energy, causing considerable erosion. While salt marshes retreated, sand accumulation increased, especially towards the mouth of the Slough (Schwartz et al., 1986). Today, sediment accumulation is occurring in the Middle to Upper Slough, and sediment erosion is occurring in the Lower Slough (Marks \& Kvitek, 2012).

The shallow, protected waters of an estuary are recognized as an important environment for the spawning and growth of young fish, including economically-valuable species (Boehlert \& Mundy, 1987; Yoklavich et al., 1991; Krygier \& Pearcy, 1986). Yoklavich et al. (1991) describe an "estuarine dependence" where an estuary, such as Elkhorn Slough, is necessary for survival during a specific stage of a species' life. Estuary environments cover 10-25\% of the U.S. west coast, which is a much lower percentage than that of the Atlantic or Gulf of Mexico coast. Additionally, these rare environments are sensitive to pollution and other human disturbances (Yoklavich, 1991). The importance and scarcity of these kinds of habitats lead to the selection of Elkhorn Slough as a part of the National Estuarine Research Reserve System (NERRS).

\subsection{Benthic Habitat Classification Scheme}

Mapping the seabed is vital for assessing and monitoring ecologically valuable environments. As anthropogenic activities, such as fishing, sand mining, harbor construction, pollution, etc. affect the coastline, benthic habitat mapping can be used to analyze their influence on sensitive ecology (Kenny et al., 2003). Benthic habitat maps can be generated using various geological, ecological, and hydrological data. Brown et al. (2011) considered the diverse methods of creating these maps, defining the term "marine habitat mapping" as "the use of spatially continuous environmental data sets to represent and predict biological patterns on the seafloor (in a continuous or discontinuous manner)".

In 1999, Greene et al. published a classification code for benthic habitats to be used in GIS. This coding system for benthic habitats progresses from large megahabitat features to small microhabitat features by assigning an alphanumeric character for each category. A megahabitat ranging from kilometers to tens of kilometers or more, such as a continental shelf or estuary, is first defined. Hardness (induration) of the bottom surface is added next, followed by macrohabitats such as canyons or deltas. Texture is denoted by a subscript letter, and the degree 
of surface slope is denoted by a number. Finally, the seafloor rugosity is given a letter and added on last. This coding system can be scaled to match the studied area (Greene et al., 2007).

A local example of where this classification scheme has been used is Endris et al.'s (2015) study of the benthic habitats of offshore San Francisco Bay, California. This study covered a deeper, larger area than Elkhorn Slough. They mapped out 31 habitat types in the estuarine and continental shelf region using bathymetry, backscatter, and ground samples. Similarly to our work in Elkhorn Slough, their map can be used to identify the variety of benthic habitats and to evaluate nearby anthropogenic ramifications and fishery management (Endris et al., 2015). Additionally, the Greene et al.'s habitat mapping scheme has been used to create 21 other 1/24,000-scale potential marine benthic habitat maps off the coast of California, approximately $34 \%$ of the coastline (H.G. Greene, personal communication).

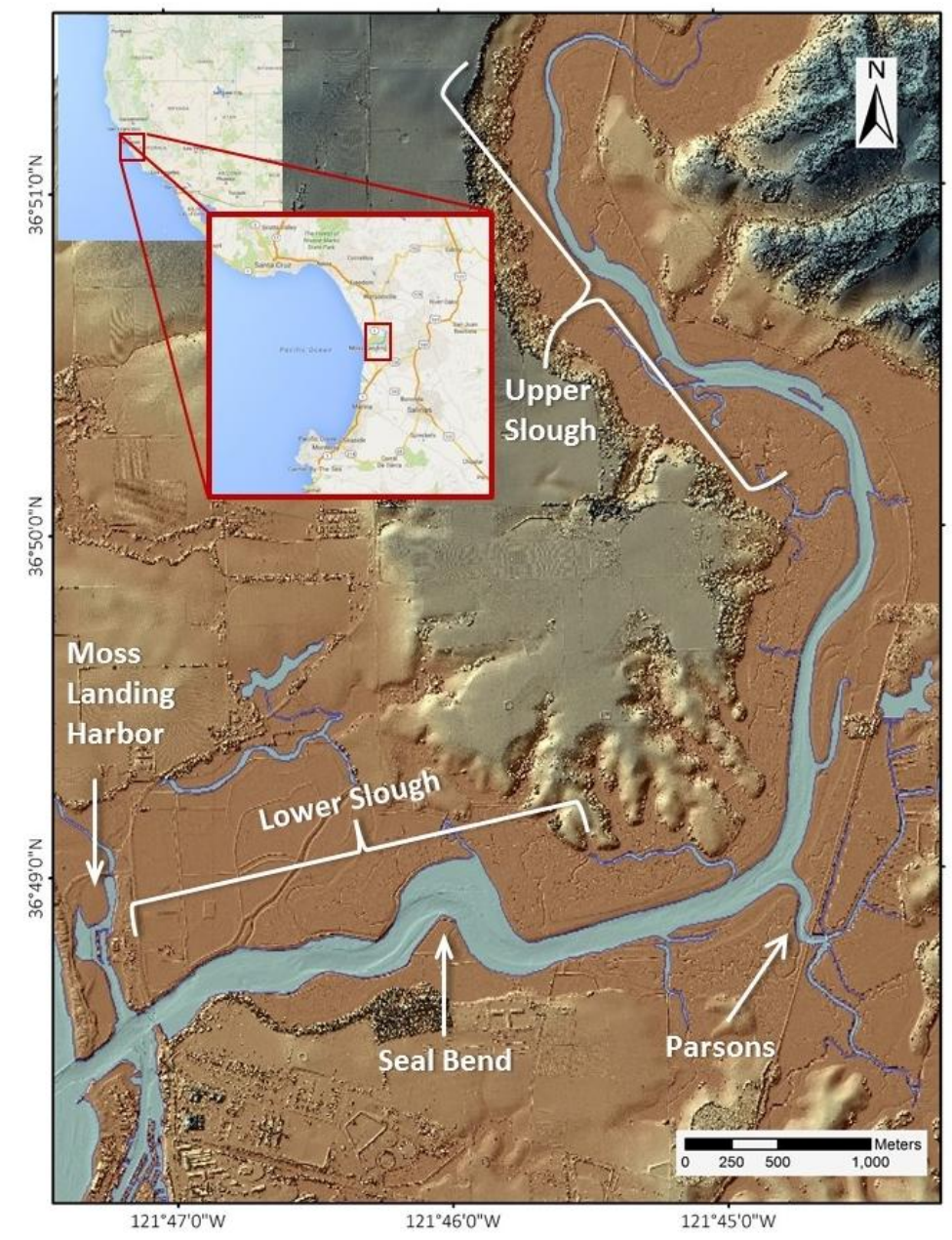

Figure 1 Study Area. The study area is located in the Monterey Bay along California's central coastline. LiDAR data courtesy of the Seafloor Mapping Lab at CSUMB. Regional maps courtesy of Google Maps. 


\section{Materials and Methods}

Eight sediment cores were taken from the shallow waters near the banks of the Slough (Table 1, Figure 3). Each core was acquired with an 8.5-centimeter-diameter PVC tube, pressed by a weight or push handle into the sediment. Once the sample was brought to the surface, the layers of sediment were examined noting color, grain size, thickness of layers, and odor (Figure 2). An accurate GPS location for each core was recorded.

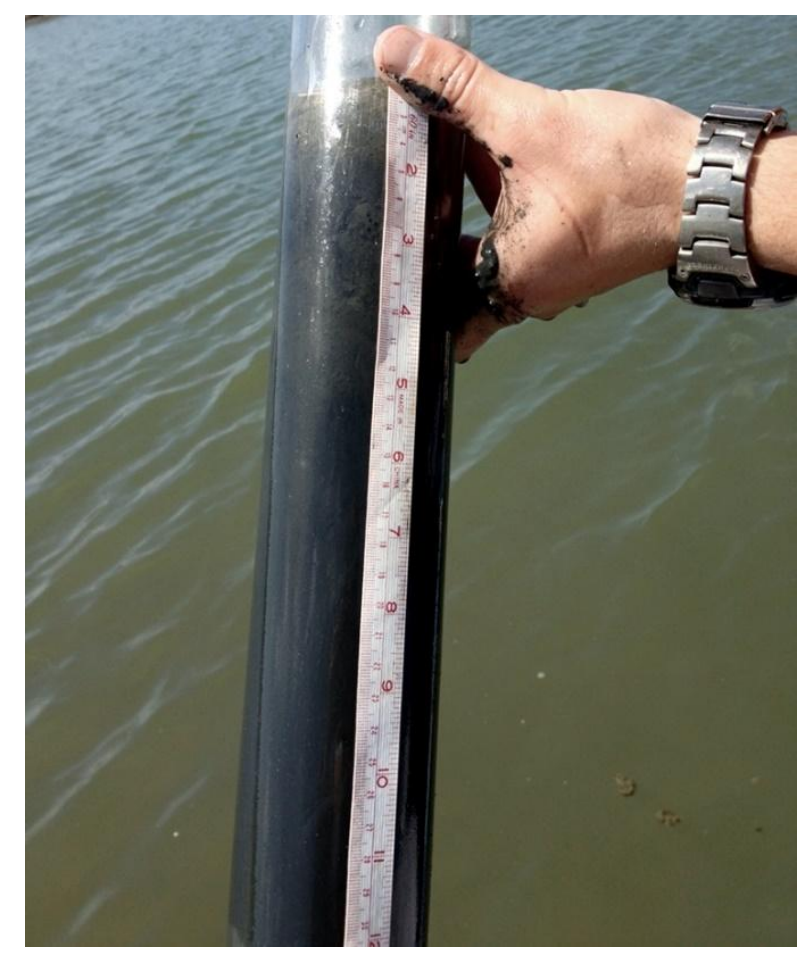

Figure 2 Big Creek 2 Core. Above are the top eleven centimeters of a core taken from the Upper Slough. The top layer was black anoxic mud with some air pockets. See Table 1 for all core descriptions and Figure 3 for all core locations.

A LiDAR image was added in to ArcMap 10.2 to serve as a background to the benthic habitat map. GPS locations of the sediment cores were added to the map. Using the recorded information from the cores taken in the channel (Table 1), the top layer was analyzed to compare the grain size distribution across the length of the Slough. A shapefile was created to represent areas of sandy sediments. A polygon was drawn from the mouth at the harbor up to just after Seal Bend. A core taken just past Seal Bend (at Rubis Creek) had a top layer of coarse mud with some sand mixed in. This was the last core found to have sand in its top layer; therefore, it was 
used as the cutoff point for the sand polygon. Another shapefile was created for mud, and a polygon was drawn over the rest of the Slough channel, where only mud, silt, and clay were found in the top layer.

As a part of the benthic habitat mapping code, the surface slope needed to be considered. Greene et al.'s $(1999,2007)$ coding system uses 6 categories for slope, including flat surfaces (0$5^{\circ}$ ) and sloping surfaces $\left(5-30^{\circ}\right)$. A bathymetric slope dataset, derived from data collected by CSU Monterey Bay’s Seafloor Mapping Lab in 2014, was reclassified to create one class for 0$5^{\circ}$ values and a second class for 5-30 values. A negligible part of the slope dataset contained values above $30^{\circ}$ and was therefore excluded. The reclassified slope dataset was then intersected with the sediment shapefile to create polygons representing areas of either sand or mud within the higher slope of $5-30^{\circ}$.

A shapefile was incorporated into the GIS project which represents the area where the primary vegetation, eelgrass, was found. This shapefile was created by drawing polygons over aerial imagery from Google Earth and the California Department of Fish and Wildlife, which were taken January and February of 2014. The shapefile was added to the map and layered on top of the sand and mud shapefiles.

Two bathymetry datasets, both collected by CSUMB's Seafloor Mapping Lab, were used to form a raster file representing the subtraction between the two bathymetry files. The first bathymetry study was conducted in 2005 and updated in 2007, and the second study was conducted in 2011. The subtraction of these two datasets gives a value of the change in depth-tosediment over those six years. A negative value represents erosion, and a positive value represents accretion.

Once this raster was uploaded into ArcMap, a classification was used to group these values into 5 categories: heavy erosion ( -0.5 to -3.9 meters), intermediate erosion ( -0.1 to -0.5 meters), negligible change $(-0.1$ to +0.1 meters $)$, intermediate accretion $(+0.1$ to +0.4 meters), and heavy accretion $(+0.4$ to +3.5 meters $)$. This data was used to create two new shapefiles. We drew polygons around regions of erosion in one shapefile and polygons around regions of accretion in the other. 


\section{Results}

The compilation of all sediment coring sites is shown below in Table 1, which has a detailed description of the different layers and the location of each core. The core taken in the Lower Slough closest to the harbor, N1W, had a top layer of fine-grained sand. The next core landward, Rubis Creek, had fine-grained sand mixed into mud on the top layer. The rest of the cores had various types of mud, peat, or organic matter on the top layer.

\begin{tabular}{|c|c|c|c|c|}
\hline Core Name & $\begin{array}{l}\text { Latitude \& } \\
\text { Longitude }\end{array}$ & \multicolumn{3}{|c|}{ Layer Description (thickness in $\mathrm{cm}$ ) } \\
\hline $\mathrm{N} 1 \mathrm{~W}$ & $\begin{array}{r}\mathrm{N} 36^{\circ} 48.799 \\
\mathrm{~W} 121^{\circ} 46.712 \\
\end{array}$ & $\begin{array}{c}0-1.5 \text { fine-grained } \\
\text { sand }\end{array}$ & $\begin{array}{c}1.5-12 \text { dark soft } \\
\text { mud }\end{array}$ & $\begin{array}{c}12-19 \text { light hard } \\
\text { clay }\end{array}$ \\
\hline Rubis Creek & $\begin{array}{c}\mathrm{N} 36^{\circ} 48.824 \\
\mathrm{~W} 121^{\circ} 45.646 \\
\end{array}$ & $\begin{array}{c}0-4 \text { coarse mud } \\
(\text { sand mixed in) }\end{array}$ & $\begin{array}{c}4-30.5 \text { fine-grained } \\
\text { soft mud/clay }\end{array}$ & \\
\hline NS3W & $\begin{array}{c}\text { N } 36^{\circ} 48.761 \\
\text { W } 121^{\circ} 45.481\end{array}$ & $\begin{array}{l}0-2 \text { soft brown mud } \\
\text { with some roots }\end{array}$ & $\begin{array}{l}2-27 \text { dark grey fine- } \\
\text { grained soft mud }\end{array}$ & $\begin{array}{c}27-32.5 \text { light grey } \\
\text { fine-grained hard } \\
\text { mud }\end{array}$ \\
\hline $\mathrm{K} 1 \mathrm{~W}$ & $\begin{array}{c}\text { N } 36^{\circ} 48.771 \\
\text { W } 121^{\circ} 45.432 \\
\end{array}$ & $\begin{array}{c}0-3 \text { brown mud with } \\
\text { some air pockets }\end{array}$ & $\begin{array}{c}3-7 \mathrm{red} / \text { orange fine- } \\
\text { grained mud }\end{array}$ & $\begin{array}{l}7-36 \text { hard grey } \\
\text { fine-grained mud }\end{array}$ \\
\hline $\mathrm{H} 2 \mathrm{~W}$ & $\begin{array}{c}\text { N } 36^{\circ} 48.758 \\
\text { W } 121^{\circ} 44.742 \\
\end{array}$ & $\begin{array}{c}0-3.5 \text { anoxic mud } \\
\text { with organics }\end{array}$ & $\begin{array}{l}3.5-35 \text { brown, grey, } \\
\text { and black mud mix }\end{array}$ & $35-41.4$ grey mud \\
\hline $\mathrm{S} 2 \mathrm{~W}$ & $\begin{array}{l}\mathrm{N} 36^{\circ} 49.748 \\
\mathrm{~W} 121^{\circ} 44.665\end{array}$ & $\begin{array}{c}0-9 \text { brown mud with } \\
\text { some organics }\end{array}$ & $\begin{array}{l}9-17 \text { brown and } \\
\text { black mud mixed }\end{array}$ & $\begin{array}{c}17-28 \text { black anoxic } \\
\text { mud }\end{array}$ \\
\hline Big Creek 1 & $\begin{array}{c}\text { N } 36^{\circ} 50.099 \\
\text { W } 121^{\circ} 44.564\end{array}$ & $\begin{array}{c}0-31.5 \text { black anoxic } \\
\text { mud/peat with some } \\
\text { air pockets }\end{array}$ & $\begin{array}{l}31.5-55.5 \text { light grey } \\
\text { mud, some medium- } \\
\text { grained sand in mud }\end{array}$ & \\
\hline Big Creek 2 & $\begin{array}{c}\text { N } 36^{\circ} 50.077 \\
\text { W } 121^{\circ} 44.532\end{array}$ & $\begin{array}{l}0-3.5 \text { organic matter, } \\
\text { light-colored } \mathbf{m u d} / \mathbf{s l i t}\end{array}$ & $3.5-35$ anoxic mud & \\
\hline
\end{tabular}

Table 1 Sediment Core Data. The core names, locations, descriptions are listed in this table. The top surface material is shown in bold.

The final benthic habitat map layer characterizes five habitat regions, all within an estuarine (E) megahabitat (Figure 3, Table 2). "Es(s)_u1" defines a habitat with sandy softbottom sediment [s(s)], unconsolidated [_u], and a flat seafloor slope [1]. This habitat spans $25 \%$ of the Slough from the mouth to just past Seal Bend at Rubis Creek. "Es(s)_u2" is the same as the previous but with a sloping seafloor [2], and it covers $7 \%$ of Slough across the same region as the previous habitat. "Es(m)_u1" contains mud, silt, or clay soft-bottom sediment 
[s(m)], unconsolidated, [ _ u ] and a flat seafloor slope [1]. This habitat covers 49\% of the Slough from Rubis Creek up the rest of the Middle to Upper Slough. "Es(m)_u2" is the same as the previous, but with a sloping seafloor [2]. It covers 9\% of the Slough from Rubis Creek to just landward of Big Creek in the Upper Slough. The final habitat, "Es(s)v(e)_u1", contains sandy soft-bottom sediment [s(s)], eelgrass covered sediment [v(e)], is unconsolidated [ _ u], and has a flat seafloor slope [1]. This habitat spans 10\% of the Slough from just landward of the mouth to just past Seal Bend. 


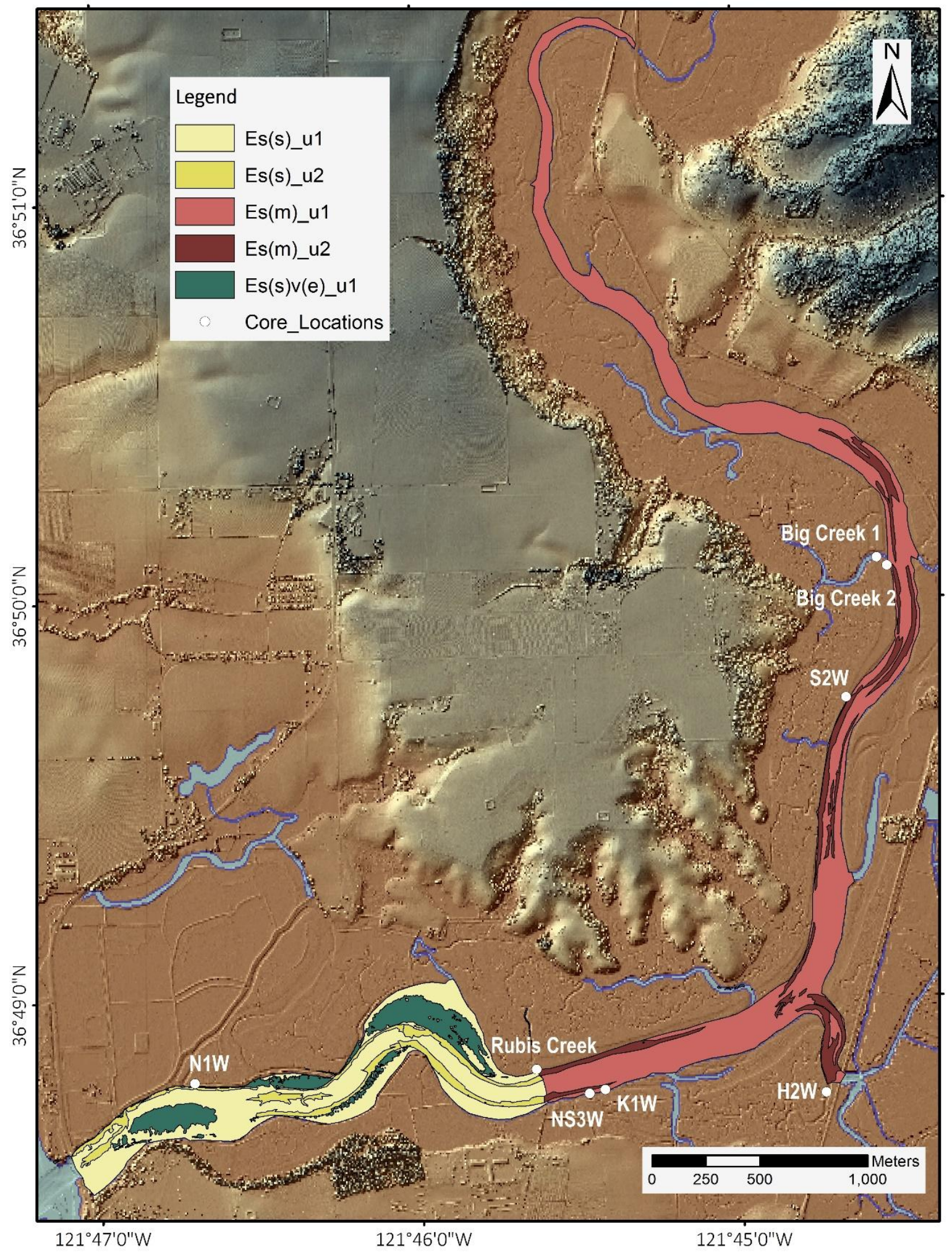

Figure 3 Potential Benthic Habitat Map. This map shows the five habitat categories of Elkhorn Slough: flat, sandy sediments [Es(s)_u1]; sloped, sandy sediments [Es(s)_u2]; flat, muddy sediments [Es(m)_u1]; sloped, muddy sediments [Es(m)_u2]; and eelgrass on flat, sandy sediment [Es(s)v(e)_u1]. The eight core locations and names are shown as well. LiDAR and bathymetry data courtesy of the Seafloor Mapping Lab at CSUMB. 


\begin{tabular}{|c|c|c|c|c|c|}
\cline { 2 - 6 } \multicolumn{1}{c|}{} & Es(s)_u1 & Es(s)_u2 & Es(m)_u1 & Es(m)_u2 & Es(s)v(e)_u1 \\
\hline Megahabitat & Estuary & Estuary & Estuary & Estuary & Estuary \\
\hline $\begin{array}{c}\text { Bottom } \\
\text { Induration }\end{array}$ & $\begin{array}{c}\text { Soft bottom } \\
\text { (sand) }\end{array}$ & $\begin{array}{c}\text { Soft bottom } \\
\text { (sand) }\end{array}$ & $\begin{array}{c}\text { Soft bottom } \\
\text { (mud, silt, clay) }\end{array}$ & $\begin{array}{c}\text { Soft bottom } \\
\text { (mud, silt, clay) }\end{array}$ & Soft bottom (sand) \\
\hline Macrohabitat & \multicolumn{4}{|c|}{$\begin{array}{c}\text { vegetative sediment } \\
\text { (eelgrass covered) }\end{array}$} \\
\hline Texture & unconsolidated & unconsolidated & unconsolidated & unconsolidated & unconsolidated \\
\hline Seafloor Slope & flat & sloping & flat & sloping & flat \\
\hline Area (km ${ }^{2}$ ) & 0.363 & 0.101 & 0.698 & 0.131 & 0.140 \\
\hline $\begin{array}{c}\text { Percentage of } \\
\text { Studied Area }\end{array}$ & $25 \%$ & $7 \%$ & $49 \%$ & $9 \%$ & $10 \%$ \\
\hline
\end{tabular}

Table 2 Elkhorn Slough's Benthic Habitats. This table explains how the five habitat regions differ. The flat seafloor slope ranges from $0^{\circ}$ to $5^{\circ}$ while the sloping habitats range from $5^{\circ}$ to $30^{\circ}$. The total studied area is 1.433 $\mathrm{km}^{2}$.

\section{Discussion}

\subsection{Sediment erosion and accretion}

Because the benthic habitat map shows sediment characteristics throughout the Slough, it is important to consider the amount of erosion and accretion currently occurring. The tide's high velocity and turbulence causes erosion and movement of the sediment, which can change the availability of habitat (Reyes, 2009).

A raster file of the area's accretion and erosion over the six year span was used to create shapefiles to represent large areas of surface change (Figure 4). The sediment erosion shapefile (red) delineates areas where the seafloor deepened between 0.5 to 4 meters. The sediment accretion shapefile (blue) delineates areas where the seafloor shoaled between 0.5 to 4 meters. 

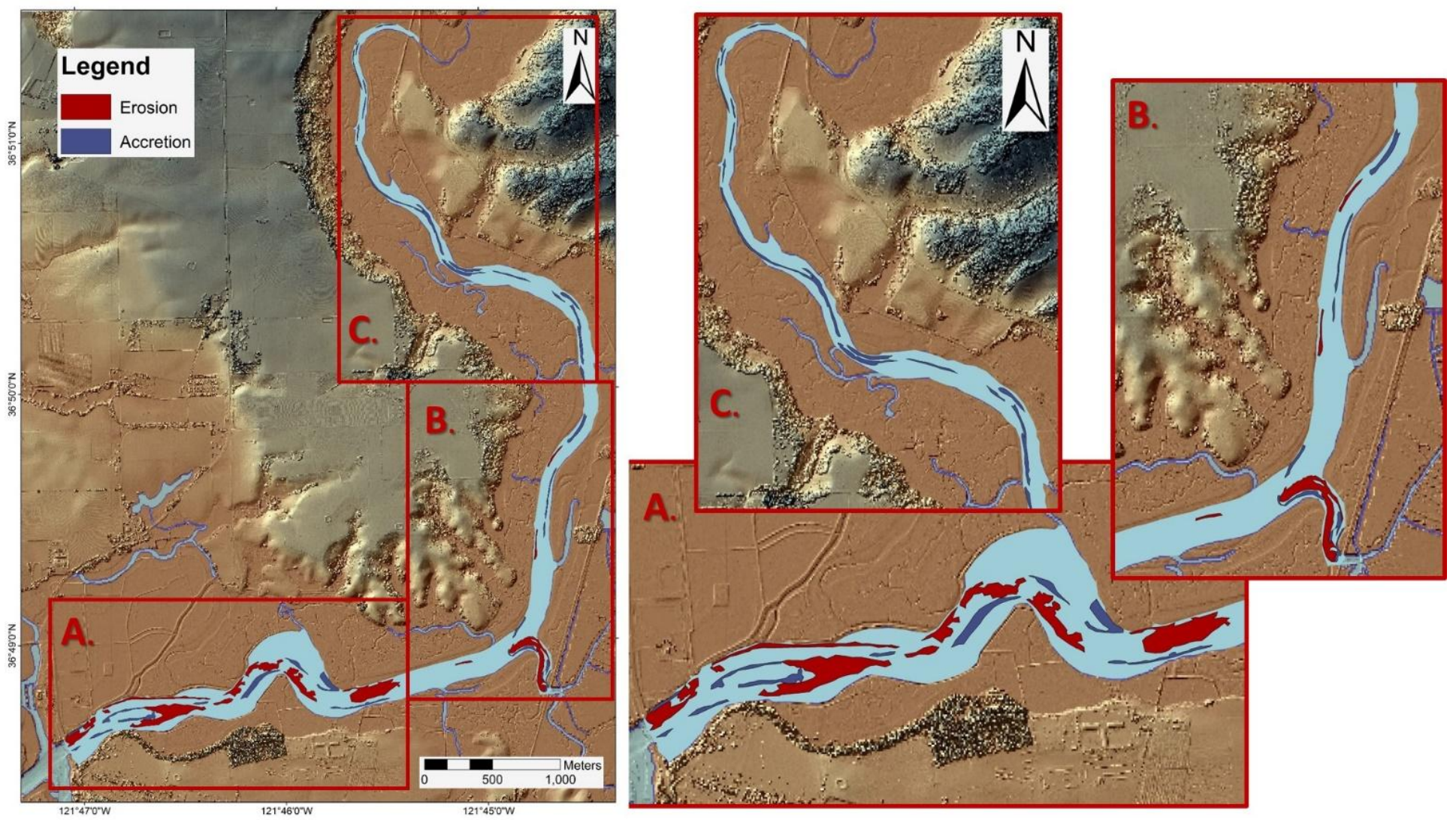

Figure 4 Erosion and Accretion Map. This map shows the region's seafloor sediment erosion (red) and accretion (blue) that was seen over 2005 to 2011. The sediment is rapidly changing, especially in the Lower Slough where tides cause movement of the sandy sediments. LiDAR and bathymetry data courtesy of the Seafloor Mapping Lab at CSUMB.

The Elkhorn Slough bathymetry erosion and accretion study has been repeated with more recent data. Figure 4 shows the erosion and accretion from 2005 to 2011, and this has been compared to that of 2011 to 2014. The time span is half of the original study, but the rate of volume of sediment change per year has changed. In the Lower Slough, erosion was occurring at $-8,300 \mathrm{~m}^{3} / \mathrm{yr}$ during 2005 to 2011 . In the following three years, the erosion rate increased to $11,300 \mathrm{~m}^{3} / \mathrm{yr}$. In the Parson's entrance (see Figure 1 for location), the erosion rate had decreased from $-2,000 \mathrm{~m}^{3} / \mathrm{yr}$. to $-1,500 \mathrm{~m}^{3} / \mathrm{yr}$. The Middle Slough showed a decrease in accretion rate from $5,300 \mathrm{~m}^{3} / \mathrm{yr}$. to $3,300 \mathrm{~m}^{3} / \mathrm{yr}$ (Endris, unpublished ESNERR report). 


\subsection{Applications of the Benthic Habitat Map}

Calculating erosion and accretion over the six-year timespan is useful in documenting the ongoing changes to Elkhorn Slough's main channel. In contrast, the habitat map provides a snapshot of the main channel's seafloor in April 2014 when the bathymetry data was collected. Together, the two datasets provide local resource managers with valuable information on where to allocate conservation efforts.

For example, ESNERR staff are currently considering the potential to re-introduce oysters to Elkhorn Slough. Maps delineating habitats and areas of erosion, then, would be especially useful tools in locating areas where oyster reef restoration could be successful. Similarly, large eelgrass restoration efforts are currently underway along the Pacific coast. The eelgrass provides food and shelter to species in shallow waters (Hammerstrom \& Grant, 2012). As ESNERR works to monitor the eelgrass, its extent combined with local sediment erosion conditions need to be evaluated. This benthic habitat map can be compared to previous and future eelgrass surveys in order to evaluate the restoration efforts.

\subsection{Further Work}

The datasets used were collected over the last ten years and vary in spatial resolution. This map could be recreated with data acquired in the same year to provide a snapshot of how the Slough's benthic habitats are today. It should be noted that this map only shows the "potential" benthic habitats of Elkhorn Slough. These studied and mapped seafloor conditions can be related to local species' habitats. However, in order to show the definite habitats, more in situ data (sediment cores and photographic data) would need to be collected.

\subsection{Conclusions}

A potential marine benthic habitat map helps to establish a crucial baseline dataset by which future mapping efforts may be compared. Understanding the present size and location of benthic habitats can be very useful for monitoring changes to the Slough's subtidal environments and for making conservation decisions (Costello, 2009; Kenny et al., 2003). 
Using sediment cores and bathymetric datasets, a map was created to display different potential habitats in Elkhorn Slough following the classification guidelines of Greene et al. (1999, 2007). The five habitats mapped include flat sandy sediments, sloped sandy sediments, flat muddy sediments, sloped muddy sediments, and eelgrass on flat sandy sediments. These habitats can be used to correlate to local submarine ecology and may serve as a tool for ESNERR's future conservation and restoration efforts. Additionally, the mapping techniques employed in this study have broad applications and can be applied to other estuaries throughout the world with only slight modifications to fit the chosen study area.

\section{Acknowledgments}

We thank Rikk Kvitek and his kelp-fly for supplying data for the erosion dataset we used. The bathymetry data used in this study were acquired, processed, archived, and distributed by the Seafloor Mapping Lab of California State University Monterey Bay. We also want to thank Ron Eby (ESNERR) and Geoff Shipton (Triton Imaging Inc.) for the time they took to help us gather the data.

Funding: This work was supported by The Non-Senate Faculty Professional Development Award [grant number 19900-433332-ESGARC] and Office of Naval Research [grant number N00014-14-1-0172.] These funding sources had no involvement in the conduct of research, data analysis, report writing, or submission for publication. 


\section{References}

Boehlert, G.W. and Mundy, B.C., 1987. Roles of behavioral and physical factors in larval and juvenile fish recruitment to estuarine nursery areas. Estuarine, Coastal and Shelf Science, 25(3) pp. 261-281. http://dx.doi.org/10.1016/j.ecss.2014.08.003.

Brown, C.J., Smith, S.J., Lawton, P. and Anderson, J.T., 2011. Benthic habitat mapping: A review of progress towards improved understanding of the spatial ecology of the seafloor using acoustic techniques. Estuarine, Coastal and Shelf Science, 92(3), pp.502-520. doi:10.1016/j.ecss.2011.02.007.

Costello, M.J., 2009. Distinguishing marine habitat classification concepts for ecological data management. Marine ecology progress series, 397, pp.253-268.

http://dx.doi.org/10.3354/meps08317.

Endris, C.A., Greene, H.G., Dieter, B.E., and Erdey, M.D., 2015, Potential marine benthic habitats, Offshore of San Francisco map area, California, sheet 7 in Cochrane, G.R., Johnson, S.Y., Dartnell, P., Greene, H.G., Erdey, M.D., Golden, N.E., Hartwell, S.R., Endris, C.A., Manson, M.W., Sliter, R.W., Kvitek, R.G., Watt, J.T., Ross, S.L., and Bruns, T.R. (G.R. Cochrane and S.A. Cochran, eds.), California State Waters Map Series - Offshore of San Francisco, California: U.S. Geological Survey Open-File Report 2015-1068, pamphlet 39 p., 10 sheets, scale 1:24,000, http://dx.doi.org/10.3133/ofr20151068.

ESNERR, 2006. Elkhorn Slough National Estuarine Research Reserve: Final Management Plan 2007 - 2011. Elkhorn Slough Key Documents. Retrieved February 16, 2016, from http://www.elkhornslough.org/keydocuments/index.htm.

García-García, A., Levey, M. D., Watson, E. B., 2013. High resolution seismic study of the Holocene infill of the Elkhorn Slough, central California. Continental Shelf Research 55, 108-118. doi:10.1016/j.csr.2013.01.012.

Greene, H.G., Bizzarro, J.J., O’Connell, V.M., Brylinsky, C.K., 2007. Construction of digital potential marine benthic habitat maps using a coded classification scheme and its applications, in: Todd, B.J., and Greene, H.G. (Eds.), Mapping the Seafloor for Habitat Characterization: Geological Association of Canada, Special Paper 47, pp. 147-161.

Greene, H.G., Yoklavich, M.M., Starr, R.M., O’Connell, V.M., Wakefield, W.W., Sullivan, D.E., McRea Jr., J.E., and Cailliet, G.M., 1999 A classification scheme for deep seafloor habitats: Oceanologica Acta, 22(6) pp. 663-678. http://dx.doi.org/10.1007/978-3-540-78761-7_32.

Hammerstrom K, Grant N. 2012. Assessment and Monitoring of Ecological Characteristics of Zostera marina L beds in Elkhorn Slough, California. Elkhorn Slough Technical Report Series 2012:3. 
Kenny, A.J., Cato, I., Desprez, M., Fader, G., Schüttenhelm, R.T.E. and Side, J., 2003. An overview of seabed-mapping technologies in the context of marine habitat classification. ICES Journal of Marine Science: Journal du Conseil, 60(2), pp.411-418. doi: 10.1016/S1054-3139(03)00006-7.

Krygier, E.E., Pearcy, W.G., 1986. The role of estuarine and offshore nursery areas for young English sole, Parophrys vetulus Girard, of Oregon. Fishery Bulletin, 84(1).

Marks, C., Kvitek, R., 2012. Combining 18 years of bathymetric surveys with terrestrial and aerial LiDAR surveys to monitor subtidal and intertidal morphology in Elkhorn Slough, California. In AGU Fall Meeting Abstracts, Vol. 1 pp. 0889.

Reyes, C.E., 2009. Effects of erosion on the distribution of subtidal communities in Elkhorn Slough, Monterey County, California (Doctoral dissertation, California State University, Fresno).

Schwartz, D., 2002. Geology in: Caffrey, J., Brown, M., Breck Tyler, W., Silberstein, M. (Eds.), Changes in California Estuary. A Profile of Elkhorn Slough. Elkhorn Slough Foundation. Moss Landing California, CA, pp. 16-24 (Chapter 2). http://dx.doi.org/10.1672/02775212(2004)024[0914:r]2.0.co;2.

Schwartz, D.L., Mullins, H.T., Belknap, D.F., 1986. Holocene geologic history of a transform Margin Estuary: Elkhorn Slough, Central California. Estuarine, Coastal and Shelf Science, 22, pp. 285-302. dx.doi.org/10.1016/0272-7714(86)90044-2.

Walton, K., García-García, A., Endris, C., 2015. Potential Marine Benthic Habitat Map of Elkhorn Slough, California. Abstract OS21A-1969. Presented at 2015 AGU Fall Meeting.

Yoklavich, M.M., Cailliet, G.M., Barry, J.P., Ambrose, D.A. and Antrim, B.S., 1991. Temporal and spatial patterns in abundance and diversity of fish assemblages in Elkhorn Slough, California. Estuaries, 14(4), pp.465-480. http://dx.doi.org/10.2307/1352270. 